\title{
Rasa Theory Applied to William Shakespeare's Twelfth Night
}

\author{
Mahendra Kumar Budhathoki \\ Lecturer in English, Campus of International Languages, \\ Tribhuvan University, Kathmandu, Nepal
}

\section{Introduction}

The primary purpose of the paper is to study Shakespeare's plays Twelfth Night (Western literature) through rasa theory i.e. an Eastern literary theory. Rasa etymologically refers to liquid, flavour, taste, elixir, essence, pleasure, beauty. Literary meaning of rasa, as Bharata defines, is that which is relished or enjoyed. He describes rasa as the delight that the readers experience the generalized emotions presented in the dramatic art. Rasa is a study of universal human emotions. "Rasa is the [...] study of emotions which deals with the delight, one takes in literature" (Poonam 5). The ultimate goal of rasa theory is to act as a catalyst to enhance aesthetic delight in literature. Rasa as the soul makes the literature alive. "The aim of performance [is] to evoke [sentiment] in the mind of audience" (Keith 314). Dramatic works appeal to human heart. "Rasa theory embraces humanism as a whole. It does not leave out any of the emotions, which could produce rasa. Rasa theory therefore is an all-pervasive humanistic theory" (Fernando 35). Readers appreciate and relish literature that provides aesthetic enjoyment.

Rasa is not identical with the occidental aesthetics. Aesthetics to the occident refers to the study of the problems of good and bad, and beauty in literature, but to the orient it is the study of beauty, fundamentally pleasant, aesthetic experience. Baldick in Dictionary of Literary Terms defines aesthetics as the "philosophical investigation into the nature of beauty and the perception of beauty, especially in the arts; the theory of art or artistic taste" (5). According to Baharata, this aesthetic pleasant experience is rasa realization. Rasa deals with the emotions aroused in readers. Aesthetic experience is the alaukika (supra-mundane) experience. It is similar with the Kant's concept of pure aesthetic experience i.e. disinterested contemplation of the art and literature which provides pleasure. The feeling of rasa does not occur from external world but a permanent sentiment of a person's sensitive heart aroused by clever means of vibhavadi of a play transforms itself onto rasa (Gupta 141). The experience of rasa is also disinterested to the mundane, worldly or personal feelings of desiring something to fulfill the needs of the real life. "Any deep aesthetic experience involves a forgetting of both ordinary time and space; one loses oneself in the experience. [...] one is steeped in that unique heightened state of aesthetic enjoyment" (Patnaik 52). 
Aesthetic experience of rasa occurs immediately after the interplay of emotions. Bharata in his Natyasastra states, "vibhavanubhava-vyabhicharisamyogatrasanishpattih", that means, the components of rasa formation are vibhava, anubhava and vyabhicharibhava produce rasa. The process of evoking emotions is similar to T. S. Eliot's concept 'objective correlative' i.e. a set of objects, a situation, a chain of events, which evoke the same emotion from the reader. Bishwanath opines that the dormant emotion (sthayibhava) is also combined with vibhava, anubhava and vyabhicharibhava in the production of rasa. Rasa theory gives a dominant room to the sympathetic readers. As an aesthetic experience, rasa refers to the impersonal or objectified delight derived from testing. We as the readers react differently to different works. The emotional expressions can be related to love, happiness, surprise, fear, suffering, anger, determination, disgust. Bhattalolata adds the concept of sadharanikarana (universalization) in rasa theory i.e. the process of rasa realization by the sympathetic audience in dramatic works of art. Sadharanikarana is the process of transferring extraordinary, distinct object and essence to ordinary, generally accepted, universal state; the process of realization of rasa is the process of sdharanikarana (Shukla 134). The emotions are transformed by art into the rasas. Emotion is considered as an essential element in the aesthetic experience aroused in literature in both the East and the West. Shakespeare has been praised for his knowledge of human heart and for rendering human experience in poetic language. Human experiences are based upon various emotions aroused in human heart. Because of the emotions, the plays are still fascinating to the readers. They lose themselves in imaginative world, and realize aesthetic pleasure, i.e. rasa.

Some literary critics are reluctant to accept the relevance of rasa theory to literature and literary criticism. It can be applied to Weastern and also recent literature because of its universility, timeless quality. It is taken up again by modern critics in the world of literature and literary criticisms. The study shows how rasa can be applicable to literary genres in terms of values, among other concepts and theories. The paper brings literature and literary criticism of the East and the West close. It makes the critics of literature aware the application of as rasa theory to Western literature.

\section{Statement of the Problem}

William Shakespeare's plays brilliantly touch the sympathetic readers' heart. The emotions of readers can be aroused by the dialogues and the activities, language and manners of the characters in drama. The pleasant experience and the emotion found while reading plays provoke me to analyze the play through rasa theory. The problem is to find out what generates pleasure and how meaning are depicted in the manner, activities and language of the characters in the play. The research questions of the study are:

What are the rasas depicted in Shakespeare's Twelfth Night? 
How are the rasas articulated in it?

\section{Objectives of the Study}

The purpose of this study is to expose the use of rasa theory to Shakespeare's play Twelfth Night. The objectives of the study are

To identify rasas in Shakespeare's Twelfth Night, To analyze how the rasas are used in it.

\section{Research Methodology of the Study}

This is a qualitative research aiming at critical textual analysis based on primary and secondary sources. The plays have been randomly selected and analyzed on the basis of four components of rasa formation: vibhava, anubhava, vyabhicharibhava and sthayibbhava, and the concept of sadharanikarana. Rasa theory supplies theoritical insights to analyze the selected texts. The research is largely based on primary literary texts and secondary theoretical and critical resources.

\section{Rasa Exposition in Shakespeare's Twelfth Night}

Twelfth Night presents ample human emotions and feelings like love affection, humour, strange, sad, etc. Shakespeare ridicules people's follies and foibles with a gentle and sympathetic touch in the play. There is a blend of everyday experience and fantasy in the play. The characters are gentle, kind, merry and humorous. The characters and incidents are from everyday life. The subject matter of the play is simply love; every character is in love. They face many problems in their love. Love is a major cause of suffering in the play. Here, the settings, characters and subject matters of the play function as the 'objective correlatives' in the production of rasa.

Rasa is experienced in any works of art. It is a subjective experience; it loses its objectivity. Rasa experience is not a normal mundane world experience, but is an experience of a universe of transcendentalism and experience of 'sublime'. It makes audience or readers transcend the self. Even unpleasant emotions and feelings stimulate pleasant taste in an artistic work. Everybody cannot enjoy every rasa experience equally. Those who have the capacity to stabilize one's mundane feeling and emotion can experience rasa. Various rasas have been identified and analyzed them respectively here. In the play, I as a rasa reader have experienced sringara rasa six times, hasya rasa seven times, vibhatsa rasa four times, adbhuta rasa four times, karuna rasa two times and raudra rasa one time, but only representative rasas are given in this article. Let us see what and how rasas are produced in Twelfth Night. 


\section{Sentiment of Love, Sringāra Rasa}

Love has been a universal theme in the literature of the world. Sanskrit literature takes love as the king of emotion (Ras-Raj); love (rati) stands supreme among the rasas. Sentiment of love also occupies a remarkable space in English literature. There are both union-in-love (samyog) and separation-in-love (Viyoga) in the theme of love. Sringāra rasa is based on the dormant emotion of rati (love). It is produced by the exciting factors such as the merits, the gestures, the objects and the setting including time and place. Sringāra rasa is articulated with the combination of vibhāva, anubhāva and vyabhichāribhāva. Sentiment of love (sringāra rasa) dominates Shakespeare's play Twelfth Night. Love and love moods are the dominating forces that affect the actions of the characters in the play.

Sringara rasa as the major (angi) rasa is produced in this play Twelfth Night. Every major character of the play Twelfth Night falls in love and desire of love with one or the next. Duke Orsino is in love with a beautiful Countess Olivia, and he has proposed to marry her many times but she rejects his marriage proposal. She mourns of her dead brother. Sir Andrew Aguecheck, a rich friend of sir Toby, desires Olivia to marry, and he falls in love with her because she is very beautiful young countess. Viola has been rescued from the wreck, and she disguised herself as a young boy Cesario. As she enters, she falls in love with Orsino. But Orsino takes Viola as a young boy Cesario. Orsino sends Cesario to Olivia to purpose love from the side of Orsino. Although Cesario carries Orsino's message to Olivia, Cesario does not heartily want to make their relation or love affairs successful because Viola/ Cesario desires much Orsino's love, and she does not want to lose Orsino. Vialo says:

\section{[Orsino] I love}

More than I love these eyes, more than my life, More, by all mores, than e'er I shall love wife. If I do feign, you witnesses above

Punish my life for tainting of my love; (V.I. 134-38)

Viola falls in love with Duke Orsino "I fond as much on him." When Viola goes to Olivia to transmit the message of Orsino, Olivia falls in love with the young handsome boy Cesario: She gives her ring to Cesario as a sign of love, and Cesario says:

I left no ring with her. What means this lady?

Fortune forbid my outside have not charmed her.

She made good view of me; indeed, so much

That sure me thought her eyes had lost her tongue,

For she did speak in starts distractedly. 
She loves sure; the cunning of her passion

Invite's me in this churlish messenger. (II.II. 17-23)

Cesario know that Olivia loves him, but Olivia does not know that Cesario is a girl: "As I am woman (now also the lady;),/ What thriftless sighs shall poor Olivia breathe?/ O Time, thou must untangle this, not I;/ It is too hard a knot for me t' untie." Here Viola loves Orsino much and Orsino loves Olivia much and Olivia fond much on Viola/ Cesario. When Sebastian enters Olivia's house, Olivia, who thinks Sebastian is Cesario, requests Sebastian to Marria secretly. Sebastian also falls in love with such a young beautiful girl Olivia, and accepts her proposal. After Sebastian, Viola/Cesario, Orsino and Olivia present at a time in Olivia's house, it is disclosed that Cesario is a young girl Viola and Sebastian is a Viola's brother. Duke Orsino loves Viola, and remembers her past saying: "thou last said to me a thousand times/ Thou never shouldst love woman like to me," and "A solemn combination shall be made/ Of our dear souls."

In the process of rasa formation, the certain components function. Since every character falls in love either with one or the next, they may function sometimes as vishayalambana or ashrayalambana vibhava. In Duke Orsino's love to Olivia, Olivia functions as vishayalambana vibhava, and Orsino functions as ashrayalambana vibhava. When Viola/Cesario falls in love with Duke Orsino, Orsino functions as vishayalambana vibhava, and Viola functions as ashrayalambana vibhava. At the end of the play, Cesario is disclosed that Cesario is a beautiful girl Viola here Orsino functions as ashrayalambana vibhava, and Viola functions as vishayalambana vibhava. In the relation of Cesario and Olivia, Cesario functions as vishayalambana vibhava, and Olivia functions as ashrayalambana vibhava. In the relation of Olivia and Sebastian, they are affected each other. Olivia functions as vishayalambana and/or ashrayalambana vibhava; at the same way, Sebastian functions as vishayalambana and/or ashrayalambana vibhava. In the relation of Malvolio and Olivia, Olivia functions as vishayalambana vibhava, and Malvolio functions as ashrayalambana vibhava. In rasa theory, vishayalambana vibhava affects ashrayalamban vibhava. Uddipana vibhava, that intensifies emotion, is studied in two types: parakiya and swakiya. In the play Twelfth Night, visiting the garden, beautiful house of Olivia and Orsino, seasons, ornaments, decorating the body, seeing and hearing pleasant things, a room in which a young boy and girl lives, etc. are parakiyauddipana vibhava. Olivia's graceful manner, Cesario's gentleness, Sebastian's behaviours, Olivia's writing to Malvolio, etc. are swakiyauddipana vibhava.

Anubhava are characters' (vishayalambana vibhava) play of the eyes and the eyebrows, glances, sweet and graceful gait, bacilli postures and words, movements, etc. Vyabhicharibhava are the feeling of intoxication (Orsino's feeling to Olivia, Viola's to Orsino, etc.), weariness (Orsino feels it when he repeatedly proposes Olivia), feeling of recollection of the past (Orsino remembers Cesario's past), feeling of delight and joy, feeling of excitement, feeling of longing somebody, state of dreaming, feeling of dissimulation and dissembling (Viola conceals her appearance), feeling of self-assurance, intellect and resolution, state of sickness, feeling of madness on of insanity, etc. The permanent emotion of sringara rasa is rati (love). 
In the context of sadharanikarana of sringāra rasa in the play Twelfth Night, here, readers or audience find the lovers and the beloveds in the play. They anticipate with the characters and feel the emotion, love. The readers or audience generalize the love affection in their society. Thus, they realize sringāra rasa which makes them enjoy his play Twelfth Night. Shakespeare depicts a universal culture of love all over the world especially with regard the relationship between young boys and girls.

Sringāra rasa is also produced in act one scene one of the play Twelfth Night. Here, Orsino speaks melancholy about his love for Olivia. This scene concerns about emotion, desire and rejection of love. Orsino has keen desire to get the Countess Olivia- "If music be the food of love, play on./ Give me excess of it" (1-2). He has fallen in love since he saw Olivia. He says that the strong desire for something (here, desire for Olivia) "may sicken, and so die". He loses himself in music -"O, it came o'er my ear like the sweet sound/ That breathes upon a bank of violets,/ stealing and giving odor" (5-7). He compares that love is like the sea that consumes everything occurs into it. He states that the true love is related to imagination. He is hopelessly in love with Olivia. For him, love has been like a hallucination. When Curio asks if Orsino will go hunt the hart, the Duke Orsino compares himself with the hart (a male deer). His strong desire for Olivia as a fierce and "cruel hound" has haunted him. Then, Valentine enters with sad news that the Countess Olivia mourns her brother who has recently died. She rejects the Duke Orsino's proposal of love. She has vowed that she will veil and will not show her face until next seven years and she will not marry anyone. He becomes sad because of her rejection, but admires her devotion to her brother's love. $\mathrm{He}$ dreams that how intensively she will love a man when the man wins her heart. Although Olivia rejects his love proposal, Orsino expects to get her love later. He feels sad, but not frustrated, about his love. He is hopeful for the state of being joined together with Olivia. So, here, sringara rasa is produced. More specially, vipralambasringara rasa is articulated. There is a sad condition of love of Orsino to Olivia. Orsino has eagerness to meet Olivia, and has anxiety whether they will unite or will not. When Olivia is not present, Orsino remembers her -"When mine eyes did see Olivia first" (20). Orsino feels sadness and addictive longing. He falls in love because of her beauty and devotion to love (her brother's love). Thus, sringara rasa is realized in the act i scene i of the play Twelfth Night.

In the process of production of sringara rasa in the act i scene i, the Countess Olivia functions as vishayalambana vibhava that causes the intense desire of love at the heart of the Duck Orsino. Orsino functions ashrayalambana vibhava that is affected by vishayalambana vibhava. Olivia's beauty, beautiful dress and her devoted love to her brother (who has recently died) serve as uddipana vibhava. The second means of the production of rasa is anubhava that is the reaction and response shown by ashrayalambana vibhava. The psycho-mental responses of the Duke Orsino such as the expression of love, listening music, comparing love with sea, comparing himself 
with the haunted hart, admiring her devotion to her brother, sending his love message to her, etc. serve as anubhava. Here, the vyabhicharibhava are longing (Orsino longs for Olivia), awakening (Orsino knows how music Olivia devotes to love), madness (Orsino is mad at Olivia), anxiety (Orsino worries about her love and union ), distress and exhaustion (Olivia rejects the proposal of Orisino, and Olivia also feels exhaustion of forceful love proposal of Orsino), weariness (Orsino feels weariness because his attempts have been failed to get Olivia's love), disease and death (Orsino feels disease and death because of love -"The appetite may sicken, and so die" (3)), heaviness (Orsino feels heaviness when Valentine brings sad news from Olivia), frustration (Orsino compares himself with the hart and when he hears that Olivia will not marry anyone until next seven years), the feeling of intoxication and insobriety (Orsino feels intoxicated by the beauty and love of Olivia), lethargy and indolence (Orsino louses in his palace), feeling of recollection (Orsino remembers his first sight at her), feeling of delight (when Orsino hears the devotion of Olivia at her brother, Orsino feels joy and admires her), feeling of unhappiness and disappointment (when Orsino hears Olivia's rejection of his proposal), feeling of intellect (Orsino feels intellect at her devotion at her brother), etc . The permanent emotion of sringara rasa is rati (love).

In the process of sadharanikarana, readers or audience share the feelings, emotions of Orsino at the beloved like Olivia. The readers or audience may also have the same condition of love of Duke Orsino, or they may hear the same type of experience in their society. They generalize the love affair of Duke Orsino to Olivia. Thus, they realize sringara rasa in this scene.

\section{Sentiment of Pathos, Karuna Rasa}

The literature of the world depicts emotions of pain and pathos. Pain or grief is the universal experience of human beings, and it is found in the literature of the East and the West. Grief ( $s o k a$ ) arising from the loss of the dearest person and wealth, or from insuperable difficulty produces karuna rasa. It stems from the unpredictable calamities, disaster, sorrows, sufferings, losses, vicissitudes, bereavements, seperations of life, disappointment, etc. It touches the readers' or audience's heart while reading or viewing the play. Karuna rasa (sentiment of pathos) is articulated by means of its determinants (vibhava), consequents (anubhava) and the transitory emotions (vyabhicharibhava). Soka (grief) is its permanent state. In actual life, one does not like to experience the feeling of pain and pathos but in literature pathetic sentiment takes readers or audience to transcendental state of universalization. The realization of universal feeling of sorrow gives an aesthetic pleasure.

In act one scene two, karuna rasa is realized. The tragic and critical condition of the dearest one and the separation of the dearest one causes a kind of feeling in the heart; that feeling refers to as karuna rasa. Here, on the seacoast of Illyria, a young woman Viola was rescued from a shipwreck. Her brother Sebastian has vanished in the storm. She does not know whether her brother is alive or is not: "My brother, he is in Elysium" (4). Here 'Elysium' is the heaven for the dead in classical mythology. She is separated from her dearest brother. This causes a feeling of sad at her heart. She 
expresses her intense feeling of sorrow: "O my poor brother, and so perchance may he be" (7). When the captain tells that he saw her brother "bind[ing] himself ... to a strong mast that lived upon the sea" (12-14), Viola's feeling of grief is increased because of his tragic condition in the sea. She almost loses her hope for reunion, until there is miracle -"Perchance he is not drowned" (5), and "O my poor brother, and so perchance may he be" (7). As a young noble woman, Viola feels a tragic condition being alone in the new place Illyria -"What should I do in Illyria?" (3). Her feeling of sadness emerges when Viola has to be detached from her dearest brother in the stormy sea. She also again hears the death of Olivia's brother and her tragic situation, and the unfulfilled love affair of Orsino to Olivia. This intensifies her sorrow. Then Viola, as a disguised person Cesario, decides to serve both Olivia and Orsino. Thus, karuna rasa is produced.

In the process of karuna rasa production in this act i scene ii, Viola's brother Sebastian (who has vanished in the sea) serves as vishayalamban vibhava, and Viola functions as ashrayalamban vibhava. The seacoast and the country Illyria is new for Viola, and the environment being alone or a young noblewoman be with unfamiliar person in the unfamiliar land serve as uddipana vibhava. Viola is in intense pain being separated from her brother is swakiyauddipana vibhava, and Viola being with the unfamiliar person in new land, no clear shelter for Viola, the remembrance of her brother, etc. are parakiyauddipana vibhava. After she finds herself in a new land, she wants to know the land ("What country, friends, is this?"), her confusion and anxiety in the new country Illyria ("What should I do in Illyria?"), her expression of sorrow ("O my poor brother"), expressing that her brother is dead ("My brother he is in Elysium"), etc., here, perform as anubhava. Here, vyabhicharibhava are anxiety (Viola feels anxiety about the condition of her brother Sebastian), longing (Viola longs and expects that "perchance he is not drowned" and "perchance may he be."), loss of consciousness ("What should I do in Illyria?"), distress (Viola feels a great worry or unhappiness because she loses her brother and she alone is in the new place), weariness, exhaustion, misery, etc. The permanent emotion is sorrow.

In the process of sadharanikarana of karuna rasa in this scene, readers or audience share the feeling of sadness and the pathetic situation of Viola, and they assume it as their own. Then they feel sorrow and sadness; it becomes generalized. Thus, they realize karuna rasa. Sentiment of Humour: Experience of Hasya Rasa

Comic rasa is one of the oldest emotions; it can be traced in the East Vedas and in the West. Humour has been a major theme in the literature of the East and the West. Comic sentiment is an important emotion for human life. It relieves the mind of human beings from tension for a while. In art or literature, humour is presented to make readers or viewers laugh and amuse. Hasya rasa is produced with the combination of vibhava, anubhava and vyabhicharibhava which are found in a circumstance of the play. A comic appearance, comic utterance or behaviour stimulates laughter to readers or viewers. Any character that wears 
funny dresses speaks in distorted languages and perform comic actions in a play is the alambana vibhava (object) of hasya rasa. Anubhavas (consequents) of hasya rasa are biting the lips, narrowing of the eyes, the nose and cheeks, perspiration, holding the sides, etc. The transitory emotions of hasya rasa are alysa (lethargy), nidra (sleep), dreaming, etc. With the help of these components, the dormant emotion laughter (hasa) is relished as hasya rasa. A broken order, unexpected comic happening, unusual language use, ironic remark, satire, etc. make readers or viewers laugh. "Where laughter (not happiness) and love are found together, the comic element will blend into the general atmosphere of fun and festivity" (Patnaik 117). Hasya rasa refers to positive states of readers' or viewers' mind as sringara rasa. Humour appeals to the readers of his plays. Shakespeare uses hasya rasa many times to make a finest comedy Twelfth Night.

Hasya rasa is produced in act one scene three of the play Twelfth Night. Here, Toby, Maria and Andrew are comic characters. They amuse in different ways. Toby tries himself to show a bit more intelligent by making witty puns. Toby tries to empathize to the condition of Olivia. Maria comments on Toby's ill behaviour. He tries to prove his drinking habits -"These clothes are good enough to drink in, and so be these boots too" (11-12). Maria comments on his "quaffing and drinking habits" (14); she teases him that he drinks a large amount of wine quickly. He has no manner how to drink. He calls Sir Andrew there "To be [Olivia's] wooer". He praises Andrew as a handsome and rich person. Maria laughs at Sir Andrew's face. She makes Sir Andrew seem stupid or not serious by making jokes about Sir Andrew, and also about Toby. Maria calls Sir Andrew a fool and prodigal, a great quarreler, a coward, the gift of a grave, and a drunk. Sir Andrew mispronounces repeatedly Maria's name, and looks like a bumbling idiot. Sir Toby and Sir Andrew joke like old friends. Sir Andrew drinks and comes to see the girl Olivia to marry her. It is a great fun. Sir Andrew thinks she will not marry him; and wants to return home the next day. But Toby flatters and persuades him to stay there one month more. It is an amusement that no boy goes with drink to see a girl to marry, and stay a month longer. This is Sir Andrew's stupidity and absurdity. There are also loose and irrelevant talks about Maria, her name, wine, etc. There is wrong pronunciation of Maria's sir name Accost. There are uncouth behavior and odd speech. It is considered that deviated, deformed, distorted forms of physical, mental and linguistic norms cause hasya rasa. Thus, here, hasya rasa is realized. Here may not be the atihasita (boisterous laughter), but here is at least laughter of ridicule (upahasita). Here is parastha hasya because Maria laughs by seeing Toby's and Andrew's behaviour, speech and manner.

In the process of the production of hasya rasa in act i scene iii, Sir Toby and Sir Andrew serve as vishayalambana vibhava, and Maria serves as ashrayalambana vibhava. Maria laughs at Sir Toby and Sir Andrew. The environment that Olivia mourns at her brother's death but her uncle Toby drinks too much and calls a boy Sir Andrew to marry her intensifies laughter; this environment serves as uddipana vibhava. As anubhava of hasya rasa, Maria's expressions like "[Sir Andrew] hath 
indeed all, most natural; for besides he's a fool, he's great quarreler; and but that he hath the gift of a coward to allay the gust he hath in quarreling, 'tis thought among the prudent he would quickly have the gift of a grave" (30-32) and "bring your hand to the' butt'ry bar and let it drink" (69), and "I let your hand; I am barren" (73), etc. Vyabhicharibhava are remorse and debility (Maria feels it when she finds Toby, and Sir Andrew drinks alcohol too much), fearful suspicion and apprehension (Maria fears when she sees Toby and Andrew who have much drunk), the feeling of anxiety (Maria has the feeling of anxiety if Olivia knows all what Toby does), delight and joy (when Andrew mispronounces Maria's sir name, and Toby jokes), the feeling of anger (Maria is angry with Toby), feeling of doubt (Andrew feels doubt whether Olivia likes him or dislikes ), etc.

In the process of universalization of hasya rasa, readers or audience laugh at Sir Toby who drinks much and wants to marry Olivia to "a fool and a prodigal" Andrew. Toby jokes and Andrew pronounces Maria's name wrongly. Maria says to Andrew "I let your hand, I am barren." Andrew, who has drunk, goes to propose Olivia. Such events and behaviours are generalized even in their real society, and readers or audience laugh at the three comic characters, namely, Toby, Maria and Andrew. Thus, the readers or audience realize hasya rasa in this act $\mathrm{i}$ scene iii.

\section{Sentiment of Wrath, Raudra Rasa}

Raudra rasa is usually associated with injustice, cruelty and oppression when such emotions are very much felt in literary works. Anger is a significant element in the literature of the East and the West. It cannot sustain itself for a long time; it can lead to good or the destruction of evil. For readers, words communicate an furious intention, anger and infliction of pain in the play. When one feels anger, $\mathrm{s} /$ he is not sure what and how exactly to act; this is an intermediary stage of raudra rasa. Krodha (anger) is the sthayibhava (dormant emotion) of raudra rasa. The person, who awakens anger in one's heart, his actions and behaviour are vibhavas (determinants) of raudra rasa. The movement of eyebrows, raising arms to strike, roaring, quivering lips, reddening eyes and face, use of power and force, etc. are the consequents (anubhavas) of raudra rasa. Distress (visada), agitation (avega), arrogance (mada), worry (chinta), recalling (smriti) are evoked as vyabhicharibhavas (transitory emotions) in raudra rasa.

Raudra rasa is articulated in act one scene five of the play Twelfth Night. When one feels some loss of honour, humiliation, disgrace or scandal, that causes feeling of shock or anger; then raudra rasa is produced. One feels to be treated badly or neglected when the expectations are not happened, and it is the base of anger. Here in this act i scene v, Feste is a servant of Olivia. Olivia expects some certain services from Feste, a servant, but Feste crosses the boundaries of a servant such as he drinks too much, be absence without information and talk too much with Olivia. Maria also gets angry with Feste because he has been absence without informing her. Maria has fear that Feste will be terminated. Here, Maria expects that Feste will ask for "excuse" 
but he becomes obstinate in his manner -"let her hang me. He that is well hanged in this world needs to fear no colors" (5-6), and is "bold to say in [his] foolery" (13). The absence and manner of talking humiliates and makes her disgrace. His disobedience to Olivia and Maria causes anger. When Olivia enters, Feste is speaking about "fools." He tries to prove his own manner wise- "Better a witty fool than a foolish wit" (35) and addresses at Olivia, "god bless thee, lady", and "take away the lady". Because of such manner of Feste, Olivia feels loss of honour, humiliation and scandal; that causes her shock or anger: Olivia says "go to, y' are a dry fool! I'll no more of you. Besides, you grow dishonest" (39-40). Feste orders people to "take her away" instead of maintain relations with the boss Olivia, and he says "give me leave to prove you a fool." He asks why Olivia mourn for her dead brother whose "soul is in hell." Olivia again gets angry- "I know his soul is in heaven fool." Feste again tells Olivia "the more, Madonna, to mourn for your brother's soul, being in heaven. Take away the fool, gentleman." Malvolio also supports Olivia that Feste is a "fool", "a barren rascal"; he also gets angry with Feste. Maria, Olivia and Malvolio get angry with Feste because of Feste's long absence and his disgraceful manner to them. Thus, raudra rasa is realized in this condition.

There are components of rasa formation that play a significant role to produce rasa. Here, to produce raudra rasa, Feste, a clown as a servant, functions as vishayalambana vibhava; Maria, Olivia and Malvolio function as ashrayalambana vibhava. The fact of being frequently away from work without information, his drinking habits, his stubborn, ways of speaking to Olivia, etc are swakiyauddipana vibhava. Olivia mourns for her brother's death, in such environment, Feaste disgraces her. This mourning environment serves as parakiyauddipana vibhava. Such uddipana vibhava heightens raudra rasa. The second component of rasa production is anubhava. Maria gets angry and warns that Olivia will terminate him for his absence long without any information. Olivia also orders her attendants to take him away, and calls him a "fool." Malvolio also calls Feste "a barren rascal", and suggests Olivia to terminate him from his job; these expressions are anubhava that are the expression and performance of feeling of ashrayalambana affected by vishayalambana vibhava. The third component of rasa production is vyablicharibhava. Here, vyabhicharibhava of raudra rasa are arrogance (Feste's stubborn about his manner), remorse and debility (Maria feels when she sees Feste who drinks much), suspicion (Maria doubts if Olivia permits Feste to continue his job), intoxication and insobriety (Feste feels when he is the state of being drank), weariness and exhaustion (Maria is exhausted by the habit of being absence of Feste), sadness (Olivia feels when she hears why she mourns for her brother's death), excitement (There is a feeling of excitement when Maria sees the drunkard Feste, Olivia discusses with the servant Feste), feeling of longing (Olivia longs for her brother ), feeling of indignation and anger (Maria, Olivia and Malvolio get angry at Feste's manner), etc. The sthayibhava of this raudra rasa is wrath or anger.

In the process of generalization of raudra rasa in act $\mathrm{i}$ scene $\mathrm{v}$, a servant, like Feste, should not have drunk too much and not be absence long without 
information. There is another expectation of a boss from a servant is the servant should respect the boss. If the servant violates such expectation, the boss feels humiliation, disgrace, loss of honour, scandal; his ego becomes dominant over the mind, and the boss gets angry. Readers or audience adopt it and realize raudra rasa in act i scene $\mathrm{v}$.

\section{Sentiment of Disgust, Experience of Vibhatsa Rasa}

The literature of the world depicts disgusting and repulsive scenes. The characters in literary works may be repulsed by something bad, very ugly, dirty or vulgar. Vibhatsa rasa seems to be one of the important rasas in the Western literature. The elements of disgust, grotesque, distrust, alienation, terror, unpleasant and disillusionment can be found in the literature of the East and the West. Disgust can be the result of realization of the gap between the ideal and the real, the expectation and the happening. Vibhatsa rasa evokes the sentiment of disgust. Vibhavas of vibhatsa rasa are hearing of something repulsive or bad omens, something ugly, stinking flesh, blood and marrow, feeling of unpleasant things, etc. Anubhavas for vibhatsa rasa are nausea, spitting, confusion, limbs trembling, face pinched, etc. Vyabhicharibhavas of this rasa can be loss of consciousness, turbulence, agitation, disease, etc. The sense of repulsion is called jugupsa which is the dormant emotion of vibhatsa rasa. The relation of vibhatsa rasa with sringara rasa is unfriendly. A distortion of love and lust can generate the feeling of disgust.

Vibhatsa rasa is found in the act two scene two of the play Twelfth Night. Vibhatsa rasa refers to abhorrence, that is, a feeling of strong hatred, especially for moral reasons, a feeling of strong dislike of something that one finds extremely unpleasant, disgusting. Here, Vialo (disguised as Cesario) and Malvolio enter from separate doors. Malvolio asks Cesario if he is the man who has currently left the Countess Olivia. After Cesario admits, Malvolio holds out the ring that Olivia asks Malvolio to return to Cesario. Malvolio thinks the ring is sent by Orsino to Olivia, and Cesario left it to her- "you peevishly threw it to her." Malvolio scornfully says that Cesario "might have saved [Malvolio] his pains, to have taken it away [himself]." Malvolio abbors Cesario and his lord Orsino -"You should put your lord into a desperate assurance she will none of him." Malvolio continuously loathes and warns Cesario -"You be never so hardy to come again in his affairs, unless it be to report your lord's taking of this. Receive it so." Malvolio throws the ring to the ground. Cesario is repulsed by Malvolio's insolent behaviour to him -"If it be worth stooping for, there it lies, in your eyes; if not be it his that finds it." And Malvolio exits suddenly and unexpectedly in an unpleasant way. Malvolio's abrupt exit also shows his disgust to Cesario. Thus, in this short scene, Malvolio expresses his repugnant manner to Cesario. Here vibhatsa rasa is produced in the act ii scene ii.

In the process of production of vibhatsa rasa in this act ii scene ii, Cesario serves as vishayalambana vibhava that makes Malvolio feel hatred to Cesario and Orsino. 
Malvolio functions as ashrayalambana vibhava. The environment in which Cesario has gone to Olivia on the behalf of the Count Orsino whom Olivia and others do not like, and a street near Olivia's house functions as parakiyauddipana vibhava; and as a servant of Orsino, Cesario's stubborn to meet Olivia functions as a swakiyauddipana vibhava. In this scene, anubhava are the dominating voice of Malvolio (when Malvolio asks Cesario "were not you ev'n now with the Countess Olivia?"), limb trembling, spitting (Malvolio asks Cesario to"put [his] lord into a desperate assurance"), throwing the ring to the ground (Malvolio throws the ring to the ground), telling "there it lies on the ground in your eyes", abrupt exit, etc. Vyabhicharibhava are turbulence (Malvolio's sudden change, confusion in his behaviour to Cesario, disagreement to Cesario's saying "I'll none of it".), loss of consciousness (Malvolio loses his consciousness what and how to speak with Cesario), paroxysm (Malvolio's sudden strong feeling or emotion that cannot be controlled - he throws the ring to the ground instead of giving at the hand of Cesario), feeling of depression (Cesario feels it when he sees the uncivilized manner of Malvolio), excitement (Malvolio is excited to detest Cesario), feeling of unhappiness (Cesario feels unhappiness in such situation), etc. The permanent emotion of vibhatsa rasa is disgust.

In the process of sadharanikarana of vibhatsa rasa, readers or audience know that Cesario is not a boy but a disguised boy and he has not thrown the ring to Olivia. They think there is no reason to hate Cesario. Readers or audience feels hatred, abhorrence, repulsion to Malvolio because of his senseless repugnant manner to Cesario; thus they realize vibhatsa rasa in the act ii scene ii.

\section{Sentiment of Wonder, Experience of Adbhuta Rasa}

The feeling of wonder has existed since the beginning of the world. Extraordinary, unexpected and unfamiliar things cause surprise to a man and fill him wonder. The excitants of the sense of wonder are supernatural occurrences, surprise twists, unique reactions of characters, extraordinary displays of personal qualities, surprise twists, a new twist to an old concept, etc. Adbhuta rasa refers to an emotion which characters (and readers) feel when they come across something extraordinary beyond the limit of normal experience and knowledge. Vibhavas of adbhuta rasa are extraordinary objects, their qualities, etc. Anubhavas of this rasa are dialation of eyes, horripilation, tears, etc. Vyabhicharibhavas of this rasa are attachment (moha), curiosity (autsukya), joy (harsa), agitation (avega), etc. The dormant emotion (sthayibhava) of adbhuta rasa is wonder (vismaya). Shakespeare has used sentiment of wonder in the play because it opens up the mind of the readers, and secures the readers' attention. Surprise being dynamic in a literary work activates aesthetic enjoyment.

In the act two scene two, adbhuta rasa is also realized. A feeling of surprise or wonder is provoked by unexpected experience, things or lack of information and knowledge. Here, Malvolio has appeared in the street near Olivia's house to return a ring to Cesario. Cesario gets surprised because he does not know about the ring. Cesario astonishingly tells Malvolio that "[Olivia] took the ring of me. I'll none of it." This event astounds Cesario - "I left no ring with her. What means this lady?" Cesario 
doubts surprisingly that Olivia may fall in love with Cesario. Cesario is filled with surprise and horror: "Fortune forbid my outside have not charmed her!" Cesario remembers his meeting with Olivia: "her eyes had lost her tongue." Cesario is sure that Olivia has fallen in love with him: "For she did speak in starts distractedly./ She loves me sure; The cunning of her passion." Cesario is startled by Olivia's invitation: "Invites me in this churlish messenger." Cesario is stunned thinking about his lord Orsino: "None of my lord's ring? Why, she sent her none." Olivia's "dream" love towards Cesario astounds Cesario because Cesario is a female in reality so she cannot love Olivia ("As I am women (now alas the day!), what thriftless sighs shall poor Olivia breathes?). Cesario has been "the pregnant enemy" to Olivia because "[Olivia] (poor monster) has fond of him." Cesario astonishingly shocks and asks "Time" to untie this knot. Thus, here, adbhuta rasa is produced.

In the process of analysis of components of rasa production, in this condition, Olivia and the ring function as vishayalambana vibhava; and Viola as disguised Cesario, serves as ashrayalambana vibhava. Viola is astounded by Olivia and the ring. After Malvolio exits, Olivia is there alone. Her loneliness with the ring in the street near Olivia house serves as a parakiyauddipana vibhava; and Viola's boyish disguise and his sound expression are swakiyauddipana vibhava. Anubhava are widening of the eyes, staring without batting as eyelid, exclamations (now alas the day!), asking surprising questions ("what means this lady?"), calling herself "poor monster" and "the pregnant enemy" against Olivia, etc. Vyabhicharibhava are perplexity (when Malvolio gives a ring, Cesario becomes confused.), doubt (Cesario doubts about Olivia's emotion of love), heaviness (Olivia does not know Cesario is a female and what will happen if Olivia knows the reality.), madness (Cesario does not know what to do or not to do), shock (the ring makes Cesario surprise and shock), horror (this surprise makes Cesario feel horror), etc. The permanent emotion of adbhuta rasa is wonder.

In the process of generalization of adbhuta rasa, here, readers or audience are also astounded by the ring and Olivia- Olivia is mourning for her brother's death and took an oath not to marry anyone, she is rejecting the Orsino's marriage proposal. But now Olivia has fallen in love with Cesario at the first meeting and she sends a ring and calls Cesario. Readers or audience get surprised by Olivia. Thus, they realize adbhuta rasa in this brief scene. Conclusion

Rasas have been identified and analyzed them respectively. The study has found sringara rasa (sentiment of love) as the angi (major) rasa in Twelfth Night; the anga (sub-ordinate) rasas articulated are sringara (love), karuna (pathos) hasya (comic), raudra (fear), vibhatsa (disgust) and adbhuta (wonder). Some rasas are articulated more than one time. The readers experience the emotions in the play when they identify themselves with the emotions and feel themselves sharing the emotions. It is claimed that srigara rasa as well as its friendly rasas, hasya rasa and adbhuta rasa, has heightened the state of being liked and enjoyed of Twelfth Night. This is the main factor that make the readers enjoy his play. 
The readers of Twelfth Night can deduce many ideas and themes viz. love, comic, jealousy, disgust, surprise, disguise, etc. The readers realize various rasas and emotions while reading the play, and they bring from the expression of the mind. For example, the readers who experience sringara rasa deduce the theme of love in the play. The readers who realize adbhuta rasa while reading the text can find the uses of supernatural thing and get surprised. They deduce the idea of wonder, surprise. Shakespeare uses love as the predominating motive that actuates the characters in the play, and this use of love activates the emotion of love in the heart of the readers or audience. Emotions, aesthetic pleasure and rasa experience that are aroused by complete deindividualisation give plays their form and life. Experience is necessary to bring them out. Such aesthetic experiences in Shakespeare's plays still fascinate readers or audience to go through. The readers or viewers experience the depth of the emotions in the play Twelfth Night when they identify themselves with the emotions and feel themselves sharing the emotions. Shakespeare aims to show the similar manner of love in the society and delight the readers or viewers by gratifying the love of almost uncommon in human experience.

\section{Works-Cited}

Barnet, Sylvan, ed. William Shakespeare: Comedies. London: David Campbell, 1992.

Bharata Muni. Natyasastra. Trans. and ed. Adya Rangacharya. Delhi: Munshiram Manoharlal, 1996.

Fernando, Gregory P. "Rasa Theory Applied to Hemingway's The Old Man and The Sea and A Farewell to Arms." A dissertation submitted in fulfillment of Doctor of Philosophy Degree to St Clements' University. August 2003. Web Gupta, Ganapati Chandra. Rasa-Siddhantaka Punarvivechana. Illahabada: Lokabharati Prakashan, 2011.

Keith, A. Berriedale. The Sanskrit Drama: In its Origin, Development Theory and Practice. New Delhi: Motilal Banarsidass Publisher, 2015.

Patnaik, Priyadarshi. Rasa in Aesthetics: An Application of Rasa Theory to Modern Western Literature. New Delhi: D K Printworld, 2013.

Poonam. Rasa Theory: An Indian Approach to Western Literature. New Delhi: VL Media Solutions, 2015.

Shukla, Ramlakhana. Sadharanikarana: Eka Sastriya Adhyayana. Deharadun: Sahitya Sadan, 1967. 